\title{
Technologies Of Using "Communicative Training" In Teaching English To 9-11th Grade Students In Secondary Schools
}

\author{
Akramova D.Sh. ${ }^{\text {a }}$ \\ ${ }^{a}$ Teacher of the Department of Language Teaching Methods, Regional Center for Retraining and Advanced Training of Public \\ Educators
}

Article History: Received: 10 November 2020; Revised 12 January 2021 Accepted: 27 January 2021; Published online: 5 April 2021

\begin{abstract}
The article provides information on the effectiveness of the use of "communicative learning" technology in teaching English in grades 9-11 in secondary schools, the effectiveness of language development in students and its application to the educational process.

Also; methods of developing English language skills in students through communicative training technology, methods of using innovative teaching methods.
\end{abstract}

Keywords: communicative training, language barrier, fluent speech, live communication

\section{Introduction}

After the independence of our country, the interest in teaching foreign languages has grown and many opportunities have been created for young people. In recent years, the demand for foreign languages has increased. A modern school graduate should be ready for effective communication, which not only allows him to show himself as a qualified specialist in his field, but also to communicate with different categories of people, to have the opportunity to work in a team.

A modern graduate should not only be a knowledgeable student, but also a "talented" student. Therefore, the development of communicative competence, speech culture comes first in the study of a foreign language.

Communicative training is training aimed at developing students' ability to communicate. The use of communicative training in teaching English develops the ability to exchange information with students, to create conditions for the most effective transmission of information.

Communicative training involves the theory and practice of managing social relationships, that is, interacting with other students. In the process of communication training, effective communication processes are developed and built, the human image and its relationship to other people are formed and maintained, and the skills to reach agreement, cooperate and recognize are developed.

Communication is an integral part of human life. No matter what lifestyle a person can lead, no matter what they do professionally - in any case, the decisive condition for its success is communication - the process of exchanging information.

Communicative training sessions focus on harmonizing students 'relationships and interactions with other students, establishing and optimizing relationships with them by interacting with them according to their goals.

Communicative training is used to solve problems in learning English through a system of lessons and extracurricular activities. An effective technology for developing communication skills and activities in English for students in grades 9-11 is education (teaching English - teaching, educating) - it is an active tool aimed at developing knowledge, skills and attitudes. lim method.

\section{Methods:}

There are many ways and means of learning languages. One of them is communicative training. In the popularity rankings, this teaching method has long and reliably ranked first among all other methods.

The communicative training method originated in the UK in the 60s and 70s. It was at this time that English began to become an international language. At that time, grammatical translation method, audiolingual and other similar techniques were available. People who had shortcomings in all of them and learned English as a foreign language found that it did not meet their needs. 
This style differs from other methods in that the fictional texts that are studied by students in other ways, far from life, are replaced by dialogues from everyday life.

Students play with them in a way that encourages each other to talk.

"Hello, my name is Sonya. I live in Kiev. I am a student »

"Hello, my name is Sonya. I live in Kiev. My student's "place" is taken by studying the topic of "dating," where they actually meet, ask each other different questions, discuss something. The first step is to discuss topics that are familiar to students in their own language. In this way, it develops in students the ability to use language on their own.

Topics should be close and interesting to students. The difference from other available methods of communication is that students who use this method do not know how the lesson will end, who will answer this or that question, it all depends on the situation. 'liq. Each lesson has new topics for discussion, new types of exercises. This is done so that students are diverse and, at the same time, never get tired of learning.

Communicative training technology is needed primarily to overcome the fear of live communication. There is an opinion that this technology is most suitable for those who have some lexical and grammatical bases of the language acquired in school, university or basic courses. Also advantages:

Students speak English from the first lesson. The communicative technology of teaching English means that students are immersed in an English-speaking environment from the first lesson. If you haven't even thought about how to speak English, then after the first lesson you will be able to learn a few dozen phrases and apply them in conversation.

Language barrier. Without any hesitation, competent speech is the main goal of the communicative approach. If the student is afraid of making a mistake in pronunciation or cannot get rid of the accent, a language barrier is created. Communicative techniques overcome all of this perfectly, as the practice of communication is devoted to almost all fixed times. At the same time, the teacher corrects your mistakes and encourages students who are not afraid to express their opinions in English.

Fluent speech. If you want to speak English as fast and confidently as you do in Russian, then in communicative training you will only talk about things you face every day: everyday problems, talking to your friends, discussing news, and so on. So you develop communication skills in English as well as in your native language.

Good understanding of the language. in communicative training you not only talk but also listen to other students. Students need to understand what the other person is talking about in order to have a full dialogue. So you develop your listening skills well. Later, you can watch original movies, listen to music and understand without any problems, as well as chat freely with strangers.

Rapid expansion of vocabulary. Communicative training technology in English lessons is designed for those who want to learn English quickly and communicate with others in it. Therefore, in the first month of reading, you will learn about 50-70 percent of the words that English people use every day. Throughout the course, you will expand your vocabulary to 3,000-4,000 words, which will be enough to travel, business trip, communication and even read the news.

\section{Discussion:}

Training is a practice-oriented intensive training. In contrast to training programs aimed at building a knowledge system, training on teaching methods focuses on the development of skills and the acquisition of new experiences by participants. English is an international language, one of the official languages of the United Nations. is one. It is the language of international communication in the fields of politics, science, technology, business, culture, trade. English is the language of navigation, aviation, literature, education, modern music, international sports, tourism, programming. 75\% of correspondence worldwide is broadcast in English, $60 \%$ of radio broadcasts are in English, more than half of the world's periodicals are in English, and $80 \%$ of electronics information is stored in English.

It is no secret that English is the most widely spoken language in the world today. There are many reasons why people learn English. One is the need for face-to-face and verbal communication with English-speaking people.

English is essential for older students because academic books and journals are in English to help broaden their intellectual and cultural worldviews. In an era of globalization and the expansion of international relations, learning English is of particular importance and opens up new perspectives for adolescents, reading, future careers and leisure. 


\section{Results.}

Effective communication with students and other teachers to provide pedagogical support to students is the key to the success of the training. Creating a supportive, friendly environment is a very important factor. Performances allow for the transfer of educational knowledge in an environment where free communication is established. Another way to improve communication skills and cross the "language barrier" is to "immersion" directly into the English-speaking environment. It is planned to speak in the native language as part of the training. Materials needed for individual and group exercises: English room; interactive whiteboard; flip chart, flip chart sheets, felttip pens, badges, projector, computer.

Summarize the results of the lessons by teachers:

\begin{tabular}{|c|c|}
\hline Reflection for students & Reflection for the teacher \\
\hline $\begin{array}{l}\text { "Reflective screen" } \\
\text { It is usually summarized at the end of the lesson, a } \\
\text { discussion of what they have learned and how they } \\
\text { have worked - that is, everyone evaluates their } \\
\text { contribution, activity, class effectiveness, fun and } \\
\text { usefulness of the chosen forms of work in achieving } \\
\text { the goals set at the beginning of the lesson. In the } \\
\text { circle, the guys speak in one sentence, choosing the } \\
\text { beginning of the phrase from the screen displayed on } \\
\text { the board: } \\
\text { 1. Men bugun bilib oldim ... (Today I have known } \\
\text { (about)...) } \\
\text { 2. Bu qiziqarli edi ... (... was interesting to me) } \\
\text { 3. Bu qiyin edi ... (.... was difficult for me) } \\
\text { 4. Men } \\
\text { (I did exercises ...) } \\
\text { 5. Men buni tushunib etdim ... (I have understood } \\
\text { that ...) } \\
\text { 6. Endi qila olaman ... (I can ...) } \\
\text { 7. Men buni sezdim ... (I felt that ...) } \\
\text { 8. Men sotib oldim ...(I bought it...) } \\
\text { 9. Men o'rgandim ... (I have learnt to ...) } \\
\text { 10. Men muvaffaq bo'ldim ... (I succeeded ...) } \\
\text { 11. Imkonim bor edi ... (I could ... }) \\
\text { 12. Men sinab ko'raman ... (I will try to ...) } \\
\text { 13. Meni hayron qoldirdi ... (... surprised me) } \\
\text { 14. Dars menga hayot uchun berdi ... (The lesson } \\
\text { gave me life ... ) } \\
\text { 15. Men xohladim ... (I would like to ....) }\end{array}$ & $\begin{array}{l}\text { The teacher gives a short story } \\
\text { about each participant of the training } \\
\text { using the materials studied. }\end{array}$ \\
\hline
\end{tabular}

The most convenient form of teaching is a lesson, because the teacher determines the number and nature of the exercises performed by students, as well as monitors their performance, prevention of errors and their correction.

Communicative training involves the use of pair and group work.

\section{Principles of group work:}

1. Communication on the principle of "here and now" - this principle limits the work of the group to the events that take place "here and now", that is, in this group at the same time.

2. The principle of personification of words means the right to speak only in one's own name and about things that are felt and experienced here and now. 
3. The principle of emphasizing the language of emotions is to avoid judgments about dignity, replacing them with descriptions of their emotional assets.

4. The principle of activity - activity as a norm of behavior in training means a real "participation" in the interaction of each member of the group in an intensive group.

5. The principle of confidential communication is sincerity, open expression of feelings and emotions.

6. The principle of confidentiality - the essence of the principle is reduced to the recommendation not to accept the content of communication that develops during extracurricular activities. Otherwise, all personal information obtained during the training will remain among its participants.

7. The principle of permanent composition of the group. The study group works most effectively, and there are special processes that help participants to express themselves, if it is closed, that is, there is a permanent group of participants, and each lesson has a constant flow of new members. 'lmaydi.

8. The principle of interaction dialogue - that is, equal and complete interpersonal communication during group lessons.

9. The principle of constant feedback - that is, the participant constantly receives information from other members of the group about the results of their actions during the training. Thanks to this reflection, a person can correct his subsequent behavior, replace unsuccessful communication methods with new ones, check the effectiveness of his influence on others. Conditions should be created in the group to ensure that participants want to express their opinions (tell others about themselves) and accept it (listen to others about themselves). Such feedback is done consciously, giving maximum developmental effect.

10. The principle of self-diagnosis - that is, the constant self-disclosure of participants, the understanding of their personal problems and the formation of a clear. The content of the lessons includes exercises and procedures that help a person to know himself, the specific features of his personality.

11. The principle of voluntary participation in both the training and its individual lessons and exercises - The participant must have a natural inner interest in changing personality throughout the group. In a positive sense, a mandatory personal change, as a rule, does not occur and should not be required of participants.

\begin{tabular}{|c|c|}
\hline Using traditional methods & Use of "communicative trainings" \\
\hline Start the lesson & Introduce the lesson by discussing a new topic \\
\hline Homework review and evaluation & $\begin{array}{c}\text { Reinforce a new topic learned outside the } \\
\text { classroom through assignments }\end{array}$ \\
\hline New topic statement & $\begin{array}{c}\text { Students learn a new topic from each other, in } \\
\text { pairs and in small groups, through presentations }\end{array}$ \\
\hline Strengthen the new theme & $\begin{array}{c}\text { Through teacher supervision, support and } \\
\text { assessment }\end{array}$ \\
\hline Homework assignment & Submit a new topic next \\
\hline
\end{tabular}

We know that in the current educational process, the student must be a subject. Focusing on more interactive methods will increase the effectiveness of education. One of the most important requirements for English lessons is to teach independent thinking. Today, English language teachers in the United States, based on the experience of English educators, use the following innovative methods:

Creative problem solving is the use of this method

the beginning of the story is read for, the conclusion is referred to the judgment of the students;

Merry riddles are puzzles for students

teaching is important in teaching English, they learn words they are unfamiliar with and find the answer to a riddle;

Quick answers help to increase the effectiveness of the lesson;

Warm-up exercises to keep students interested in the lesson

use a variety of games in the classroom;

"Pantomime" (Pantomime) This method should explain very difficult topics

in class or when written exercises are done and students are tired

can be used; 
A chain story method is the process by which students speak

helps to increase and strengthen memory;

Acting characters are used in all types of lessons

can be used. Interpreter, Translator,

Professionals such as Writer and Poet are involved with the class

can talk;

Thinkers meeting with W. Shakespeare, A. Navoi, R. Burns

poets and writers can be "invited". At this point, they said

the use of words of wisdom in the classroom makes young people perfect

helps to be educated;

When pictures speak is more convenient,

in teaching English, in the development of students' oral speech

helps to use pictures related to the topic;

Quiz cards are cards based on the number of students

which is distributed and allows all students to attend the lesson at the same time

which saves time.

The purpose of these interactive games is the cooperation between the teacher and the student, the active participation of the student in the educational process, and the main thing is intelligence.

to make the lesson fun and memorable.

\section{Conclusion.}

On the basis of communicative training in the approach to teaching English in grades 9-11, the lecture is studied at home, and the analysis is carried out in the classroom with the teacher and the audience. The lecture, which should be studied at home or outside the classroom, can be watched by the student as a video or ppt.presentation, studied and discussed with peers.

Students take control of the learning process, that is, they receive information from different sources and form their knowledge, not from a single teacher.

Speaking a foreign language is an effective way to develop speech.

In the classroom, the teacher can spend more time with the students. The teacher is the instructor communicator in English, and the student and the audience are the main communicators. In the classroom, students are active participants, not passive learners. Discussions and critical questions of students are formed naturally in the context of extracurricular learning. Interpreting the same content for a teacher is common in English-speaking classrooms, as there are usually students with different levels of language proficiency and language skills. No language teacher can deny the fact that students with high levels of language skills are bored in the classroom, or students with low levels of language skills do not understand the topic. In the communicative training approach, each student is approached individually, and students who are prepared for the classroom in advance naturally develop confidence in their knowledge and natural communication in the classroom.

In short, the organization of communicative training in English classes develops students' logical thinking skills, fluency, and the ability to respond quickly and correctly. Such methods stimulate the student's interest in knowledge. The student strives to prepare well for the lessons. This makes students the subjects of the educational process.

\section{References}

Gulyamova M.X. The role of integration of speech activity in the development of communicative competence // Foreign languages in the system of continuing education

The role of innovative educational technologies in improving the effectiveness of teaching: Resp. scientificpractical conference mat. - Tashkent, 2019. -B. 80-81.

Mitchell. The communicative approach to language teaching, New York, 2004.-pp.56-60. 
Skehan. P. Second language acquisition research and taskbased nstruction. Challenge and Change in Language Teaching. Oxford., 2003.-pp.90-93.

Cherevichko T.V. Theoretical bases of hospitality. - M .: FLINTA, 2015. - 211p.

Shabalina E.V. English for the restaurant business (English for

Catering): uchebn. posobie. - Ekaterinburg: Akademiya turizma i mezhdunarodnyx otnosheniy, 2017. - 56p.

Shumova I.V. Active methods of training as sposob povisheniya kache-

stva professionalalnogo obrazovaniya // Pedagogika: traditsii i innovatsii: materialy mejdunar. zaoch. nauch.

konf. / pod obshch. ed. G.D. Axmetovoy. - Chelyabinsk: Two Komsomols, 2011. - p. 57 - 62.

Glossary of terms in general and social pedagogy / sost. A.S. Voronin. Ekaterinburg: EGPU, 2006. - 523 p.

Soldatov A. I am a business coach: Secrets of adult auditory training.

- M .: Alpina Didjital, 2017. - 172 p.

Solovova E.N. Methods of teaching foreign languages: Basic course:

posobie dlya studentov ped. universities and teachers. - M .: AST: Astrel, 2009. -

$238 \mathrm{~s}$.

Timoxina T. L. Gostinichnyy servis: uchebnik dlya srednego professionalnogo obrazovaniya. - M .: Yurayt, 2018. - 331 p. 